\title{
StruCtural Controls on the MorPhology OF THE SNAP LAKE KIMBERLITE DYKe \\ Duncan McBean ${ }^{* 1}$ Melissa Kirkley $^{1}$, and Cliff Revering ${ }^{1}$ \\ ${ }^{I}$ De Beers Canada Mining, Inc
}

\section{INTRODUCTION}

The Snap Lake kimberlite dyke, located approximately $220 \mathrm{~km}$ northeast of Yellowknife, Northwest Territories, Canada, is emplaced into the Archean Slave Province craton. The kimberlite dyke is exposed on the Northwest Peninsula of Snap Lake, is gently dipping to the northeast, is on average $2.8 \mathrm{~m}$ thick and has been delineated, to date, over a 3 square kilometer area (Figure 1). Rb-Sr age dating by Geospec Consultants (1999) produced an isochron age of $523 \pm 6.9 \mathrm{Ma}$, indicating emplacement during the Mid to Late Cambrian.

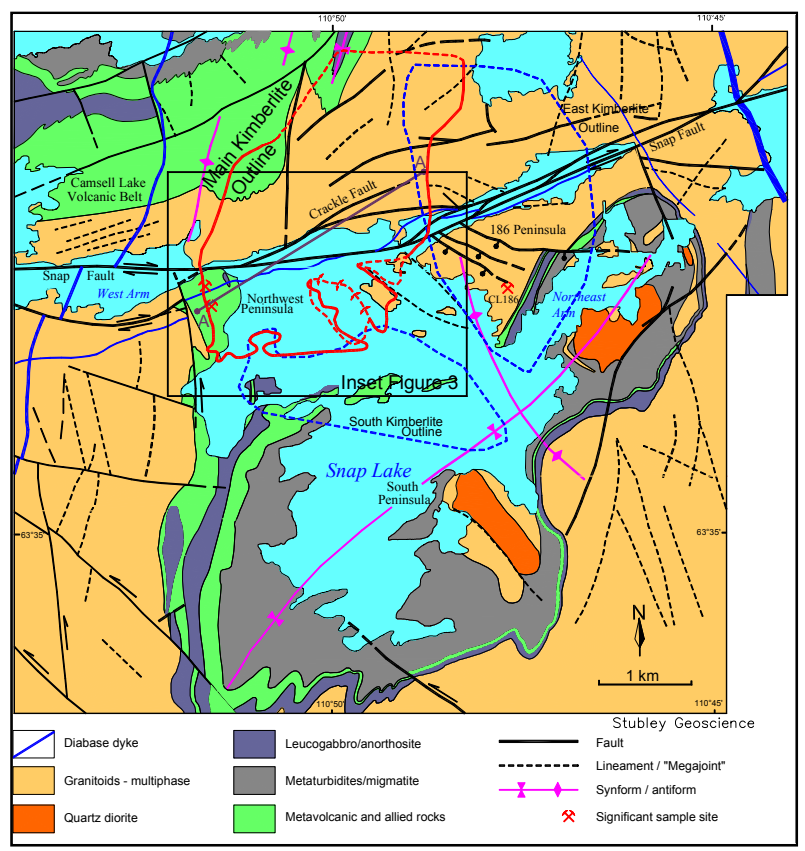

Figure 1: Snap Lake Dyke Location

A majority of the Snap Lake kimberlite dyke is hosted within an Archean multiphase suite of intrusive granitoids, with a minor portion of the kimberlite dyke emplaced within overlying metavolcanics and metasediments of the Archean greenstone belts (Stubley, 1998).

On the regional scale (100s of meters) the Snap Lake dyke appears to be a simple continuous, gently dipping sheet, although three areas of offset have been identified. Two of the offsets appear to be due to the kimberlite magma encountering host rock structural features that offset the direction of magma flow, and a potential third offset has been indicated in a 2D seismic image. On the local scale, i.e. 10s of meters, the dyke is controlled by local host rock features. Within the strongly folded metavolcanic host rocks the dyke takes on a rolling and undulating form being affected by foliation fabric. In the more brittle granitoid host rocks, the kimberlite has intruded along a primary set of joints that are flat lying but is affected by secondary jointing at approximately $35^{\circ}$ dip giving an angular step like nature to the dyke. On the intermediate scale of 10 to 100 meters, discontinuities that have been identified include dyke orientation changes, ranging to $30^{\circ}$ of expected strike, and large splays off the main dyke. Although the dyke splits around host rock features creating branches or splays and separate lenses, no complete breaks in the dyke have been identified in the 1100 meters of underground development to date.

The origin of the sub-horizontal zone of weakness in the crust, into which the Snap Lake kimberlite dyke was emplaced, is presently unknown. Several theories of emplacement have been proposed. It has also been proposed that the Snap fault, a major regional Proterozoic structure in the Snap Lake area, is a likely candidate as the conduit for the Snap Lake kimberlite. The Snap fault could have served as a vertically oriented feeder for the dyke, and the dyke spread laterally when shallower crustal levels were encountered (Stubley, 2000; Watkeys, pers. commun.). McCallum (2000) suggested that repeated episodes of reactivation along the Snap fault system created a complex set of tension 'R1" type fractures that would be at a low angle, $<20^{\circ}$ (conjugate of $70^{\circ}$ to $90^{\circ}$ to the main fault). Kirkley (2001) proposed that compressional stresses within the Slave craton could have opened sub-horizontal fractures creating an avenue of emplacement.

\section{MORPHOLOGY OF THE SNAP LAKE KIMBERLITE DYKE}

The Snap Lake kimberlite dyke is exposed in a subcrop on the Northwest Peninsula of Snap Lake, dips at $15^{\circ}$ to the northeast, and on the large scale is an apparently simple, continuous, gently dipping sheet. Drill tested intersections and underground exposures show this 
main dyke to be predominantly homogeneous, averaging 2.8 meters thick and overall 1 to 7 meters thick with one drill intersection over $14 \mathrm{~m}$ thick. The main dyke extends for a total drill tested extent of 3.3 $\mathrm{km}$ to the northeast from its exposure at the surface and is $980 \mathrm{~m}$ below surface at that point. This subhorizontal body is considered to be a dyke rather than a sill because it crosscuts the regional fabric of the host rocks.

Kimberlite dyke drill intersections on the east and south side of Snap Lake may be related to the main dyke but cannot be confidently connected due to the lack of data at this time (Figure 1). Drilling from the east side of Snap Lake on the "Eastern dyke" shows this kimberlite to be of similar material to the main dyke, oriented northeast - southwest, dipping at approximately $25^{\circ}$ northwest, and 1.5 to $2 \mathrm{~m}$ thick. Because all underground development and drilling definition work has been completed on the main dyke, the focus of this paper is the main dyke.

The Snap Lake dyke has been tested by dominantly vertical drill holes at $70 \mathrm{~m}$ spacing on the Northwest Peninsula, 150 meter spacing onto the lake and the north shore of Snap Lake, and spacing of up to several hundred meters at the farthest tested extents. A majority of drill holes intersect a single kimberlite horizon, or more than one horizon but with one interval dominating. Approximately $15 \%$ of the drill intersections show the main kimberlite dyke to be split into numerous stringers over a distance up to 5 meters. As yet, the extent of the stringer zones beyond a given drill intersection is not known.

Underground development on the $320 \mathrm{~m}$ and $280 \mathrm{~m}$ elevations has provided further evidence that the dyke is most commonly a single continuous horizon. The $320 \mathrm{~m}$ elevation has shown the dyke to be continuous, with no complete breaks, over a distance of 600 meters along strike in the metavolcanic host rocks, and the 280 $\mathrm{m}$ elevation development has shown continuity over a $100 \mathrm{~m}$ strike length by $100 \mathrm{~m}$ dip length in multiphase granitoid host rocks.

\section{REgional SCALE MoRPhology}

The Snap Lake dyke was originally interpreted by connecting the drill hole intersections to produce a consistent horizon of kimberlite dipping at approximately $15^{\circ}$ toward the northeast (Figure 2a). The elevation contours of the upper (hangingwall) contact in this original interpretation show a general dip to the northeast with a minor portion of the dyke in the southern extents dipping to the south.

Local areas of complexities are illustrated in the contours where the dyke horizon dip is greater than $15^{\circ}$. These areas of steep dips suggest that the dyke could be broken or offset. An offset in Area 1 has been confirmed through extra drilling to be approximately $100 \mathrm{~m}$ (Figure 2b). Area 2 has not yet been drilled in detail but its similarity to Area 1 suggests an offset of similar magnitude.

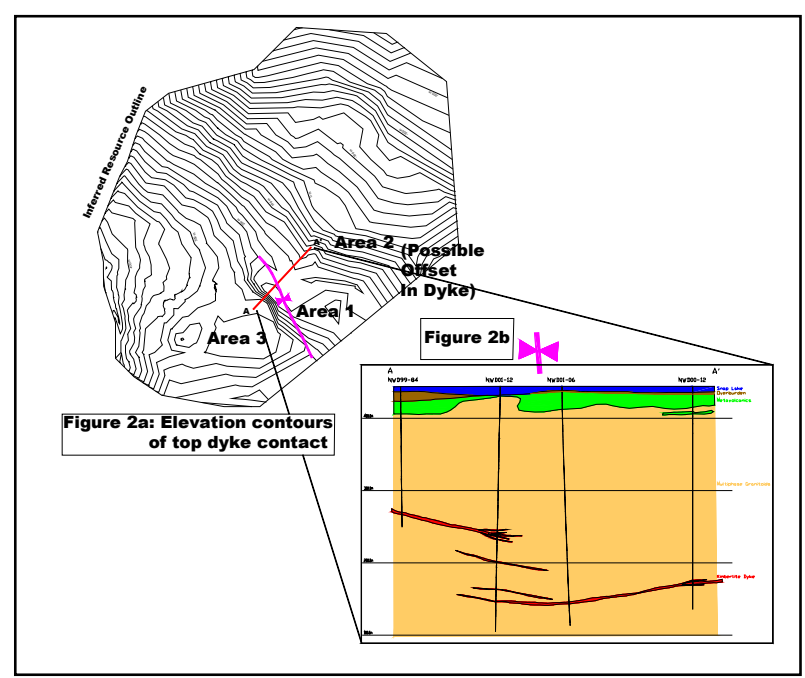

Figure 2: (a) Plan view of interpreted elevation contours of top dyke contact and areas of regional scale changes in dyke orientation. (b) Cross-section illustrating offset in Area 1.

The offset features of the kimberlite dyke described above may be the result of emplacement into structurally complex areas which diverted the magma into separate pathways. The $100 \mathrm{~m}$ offset in Area 1 is within multiphase granitoid host rock and coincides with the axial trace of a syncline associated with a late stage folding event (Figure 3, and Stubley, 2000). The granitoid host rocks in this area exhibit weak to moderate foliation similar to the contact with the overlying supercrustal package. The orientation of the dyke, on the east limb of the fold, appears to mimic the fold and dips to the west. On the west limb of the fold, the thicker, kimberlite volume continues at the expected ( $15^{\circ}$ dip) elevation and is $75 \mathrm{~m}$ above the lower thin horizon. Further, drill data to the north beyond the fold nose shows the dyke to be continuous, i.e. no offset is apparent. 


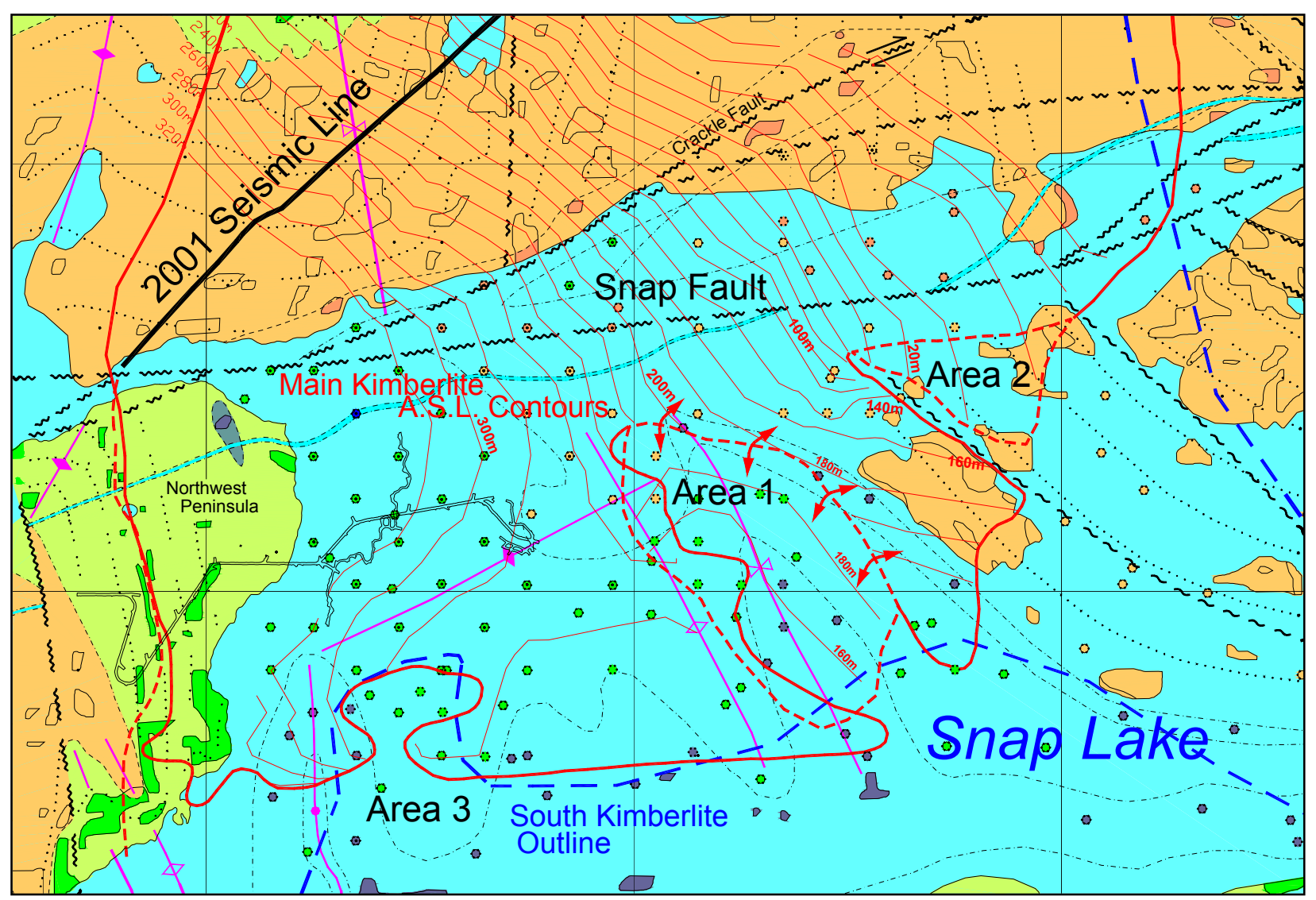

Figure 3: Inset figure showing structural controls on kimberlite dyke emplacement in Areas 1, 2 and 3.

The offset in Area 2 is coincident with a MAG-EM feature that is interpreted to be a fault structure. This fault structure, although not exposed on land, correlates with a series of mapped northwest trending structures on the east peninsula of Snap Lake.

Also shown in the cross section, Figure $2 b$, is the kimberlite feathering at the offset, as evident by several small kimberlite intersections in drill core. This feathering or 'horsetail' signature is evidence of the ends of vertical dyke lenses in South Africa (Gurney and Kirkley, 1996), and such 'horsetail' intersections at Snap Lake also appear to occur at areas where the kimberlite dyke is offset. Two dimensional (2D) seismic evidence from a survey completed in 2001 shows that the dyke is generally continuous over the length of the test area (Hammer et. al., 2003). Apparent breaks in the seismic image may be attributed to areas where the dyke is less than $1.5 \mathrm{~m}$. One such break in the seismic image coincides with a potential northsouth fault from surface mapping and with one drill hole intersection illustrating feathering in the dyke. This near vertical drill hole intersected 10 kimberlite zones, mostly 0.01 to $0.50 \mathrm{~m}$ thick with the thickest at $1.25 \mathrm{~m}$, over a $14 \mathrm{~m}$ drill length. Therefore, 2D seismic evidence, surface mapping, and this drill hole are indicating a potential offset of the dyke in this area.

Another feature evident on the regional scale is the continuation of the kimberlite body across the Snap Lake Fault, with no apparent offset. The Snap-Crackle fault zone has an east-northeast strike and near-vertical dip and is largely annealed by quartz-hematite crystallization with broken zones occurring intermittently in core drilled through the zone. Drilling on both sides of the fault zone indicates that the dyke crosses the fault without disruption in the dyke's regional $15^{\circ}$ dip. No significant movement appears to have occurred on the fault zone since the Proterozoic.

\section{MID-SCALE (10-100 M) DYKE MORPHOLOGY}

Underground development and detailed drilling have shown the Snap Lake dyke to have a greater degree of variability in strike/dip orientations, and more numerous mid to large scale splays off the main dyke, than could be interpreted from the original exploration drilling. The areas of complexity from underground exposures described herein comprise approximately 20 to $25 \%$ of total exposed kimberlite dyke to date. 
The first area of evidence from drill data is in Area 3 (Figure 2a), where the hangingwall contact contours show an apparent circular depression in the dyke. Subsequent definition drilling in this area confirmed a break in the dyke. Re-interpretation based on this drilling indicates a general east west trend to the main dyke that is relatively flat. The main dyke appears to be thinning and eventually terminates to the south. A second 1.2 to $2 \mathrm{~m}$ wide horizon, offset approximately $25 \mathrm{~m}$ below the main dyke, appears to continue to the south. In the closest drill hole intersection located 100 $\mathrm{m}$ to the north, there is only one dyke horizon intersected, but where and how this lower horizon joins the main dyke remains untested.

Development on the $320 \mathrm{~m}$ elevation showed the strike orientation of the kimberlite dyke, generally in zones up to approximately $100 \mathrm{~m}$ strike length, to vary between $360^{\circ}$ and $030^{\circ}$ while maintaining an overall trend of north-northeast (Figure 4). Deviation from the subhorizontal plane occurred in two locations, the first being a split in the dyke (Figure 4, section A-A') where the dyke ramps up and over and rejoins itself and the second being a roll in the dyke (Figure 4, section B-B') where the dyke temporarily dips to the west before resuming normal east dip.

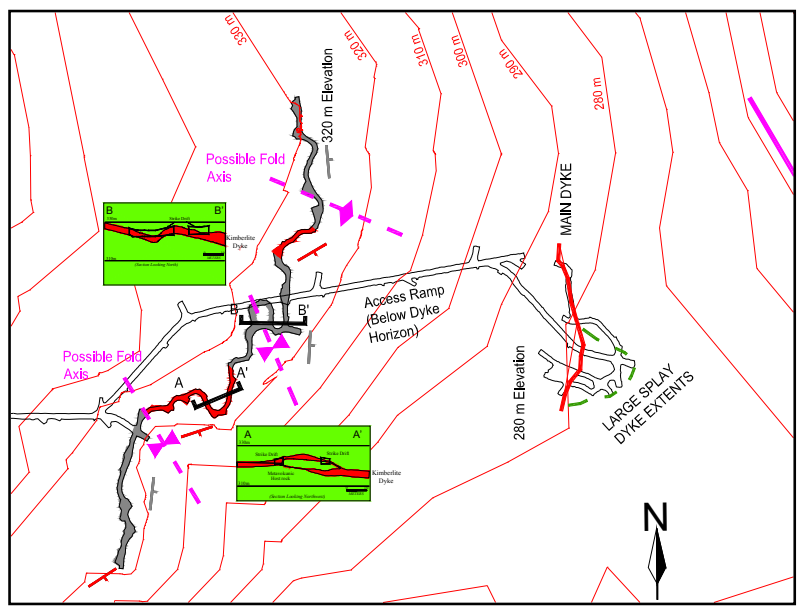

Figure 4: Plan view showing contours of the dyke top contact and underground development on the $320 \mathrm{~m}$ and $280 \mathrm{~m}$ elevations.

Host rock structural influences can also be called upon to explain these medium and small scale dyke morphological features. Surface mapping in Area 3 shows this $25 \mathrm{~m}$ apparent offset to coincide spatially with an isocline fold axis (Figure 3; Stubley, 2000). The interval zones of strike variation between $360^{\circ}$ and $030^{\circ}$ and the roll zone, described in cross section B-B' (Figure 4), appear to be the result of folding in the host rocks causing the kimberlite dyke to have a rolling or undulating form. The kimberlite dyke clearly cross cuts intensely folded layering of the metavolcanic host rocks and the reason for this undulating nature of the dyke is unknown. The area of bifurcation around a host rock feature (Figure 4, section A-A') appears to be caused by a "ramping" effect along inherent foliation. At this location the metavolcanic rocks are strongly foliated plunging at approximately $50^{\circ}$. The kimberlite dyke follows or parallels this structural plane over a short distance, creating a split in the dyke over a lateral distance of $10 \mathrm{~s}$ of meters. This tendency to follow foliation planes is also illustrated on the small scale, with ramps or jumps of up to $1 \mathrm{~m}$ parallel to foliation.

During development of the access ramp into the $280 \mathrm{~m}$ dyke elevation, both the main dyke and a splay dyke were encountered (Figure 4). Preliminary strike development took place on the splay dyke along strike and up dip until the junction of the splay with the main dyke was encountered. This splay zone measures laterally approximately 50 by $50 \mathrm{~m}$, is $1.5 \mathrm{~m}$ thick at its junction with the main dyke, and thins to $<0.10 \mathrm{~m}$ at its extremities. Mapping evidence at the join area to the main dyke shows the kimberlite utilizing a moderately dipping fracture plane at $30^{\circ}$ to $60^{\circ}$ dip over approximately a $2 \mathrm{~m}$ distance before carrying on in a sub-horizontal fashion. Structural mapping shows a sub-horizontal joint set serving as the primary emplacement control, while a $30^{\circ}$ to $60^{\circ}$ joint set serves as a secondary emplacement control into which kimberlite magma intrudes over short distances.

\section{Small Scale (<10 m) DyKe MoRPHology}

On the small scale, the Snap Lake dyke, as evident from underground exposures to date, ramps up or down 0.10 to $1 \mathrm{~m}$ distance. These ramps appear to be locally controlled by fractures and foliation in the host rocks.

Snap Lake dyke characteristics, within the more brittle granitic host rocks, are of an angular step like nature. The best evidence of this is along the terminus of the mid-scale splay described above. Where the splay thins to less than $0.5 \mathrm{~m}$ thick, it steps up or down to $1 \mathrm{~m}$ from the dominant sub-horizontal plane of emplacement. Within the multiphase granitoid host rocks, the dominant fracture orientation is sub-horizontal and subparallel to the main dyke. Local variability is associated with a secondary moderately dipping $\left(30^{\circ}\right.$ to $60^{\circ}$ ) fracture set that controls dyke emplacement over short intervals and gives the dyke a step like nature.

It is useful to study the small scale features of the dyke, as they can illustrate what may happen on the midscale, and possibly even on the larger scale. For example, detailed study of the nature of dyke emplacement at the small scale showed a kimberlite splay to bifurcate or break into several zones when 
crossing a small scale fault zone. This morphology may be analogous to the main dyke emplacement at major fault zones.

Other features observed on the small scale are local areas of anomalously $(>7 \mathrm{~m})$ thick kimberlite dyke. Near the north end of the $280 \mathrm{~m}$ elevation, the dyke thickens to just over 7 meters over an approximate development length of 10 meters. Narrow kimberlite stringers splay off this thick zone and terminate within meters of the bulge area. A second area of significant thickening occurred in one drill hole that targeted the dyke-Snap Fault intersection. This drill hole intersected altered kimberlite and brecciated kimberlite for approximately $11 \mathrm{~m}$ core length followed by approximately $6 \mathrm{~m}$ of more typical 'main kimberlite', all within faulted broken and altered multiphase granitoid host rock. The altered kimberlite is grey with a vuggy texture and apparently non-macrocrystic, or the macrocrysts have been intensely altered. In the $11 \mathrm{~m}$ zone, there is no definable contact between the kimberlite breccia and the altered kimberlite. This is the only such occurrence of this altered kimberlite encountered to date.

The broken, fractured nature of the Snap fault may be the reason for the thicker zone of kimberlite that was intersected at the Snap fault/dyke junction. There is no faulting exposed in the development at the north end of the $280 \mathrm{~m}$ elevation but the kimberlite may be using a zone of increased fracture intensity.

\section{PROPOSED EMPLACEMENT MODELS}

The unusual sub-horizontal orientation of the Snap Lake dyke has been proposed to be the result of intrusion into a compressional stress regime, in part because the Slave Craton is a craton characterized by compressional tectonics (Kirkley, 2001). This theory proposes that compressional stresses within the Slave craton could have opened sub-horizontal fractures creating an avenue of emplacement. This is in comparison to sub-vertical nature of kimberlite dykes in South Africa, which intruded into the Kalahari craton that is characterized by extensional tectonics (e.g. the break up of Gondwanaland).

Other possible emplacement models for the dyke have been proposed whereby a vertically oriented feeder for the dyke occupies the Snap Fault zone and the dyke spread laterally when shallower crustal levels were encountered (Stubley, 2000; Watkeys pers. commun.). Stubley (2000) proposes that the fractured fault zone, where healed by extensive quartz infiltration, may have caused the kimberlite magma at shallow depths to use other "unhealed" fracture systems that provided an easier ascent path. McCallum (2000) suggested that repeated episodes of reactivation along the Snap fault system created a complex set of tension 'R1' type fractures that would be at a low angle, $<20^{\circ}$ (conjugate of $70^{\circ}$ to $90^{\circ}$ to the main fault).

The apparent deep crustal nature of the Snap Fault makes it a likely candidate as the conduit for the Snap Lake kimberlite dyke. The Snap Fault is a major regional Proterozoic structure in the Snap Lake area forming the elongate east-west shape of the lake along the north shoreline. This fault system is interpreted as having initiated as a rift structure with significant vertical displacement followed by 500-600 m dextral displacement in subsequent re-activations (Stubley, 2000). Normal faults and a prominent system of joints can be demonstrated to nucleate on, and diminish in intensity with distance away from the fault zone. Whether there is a kimberlite feeder within the fault, below the horizontal elevation of the main dyke, has yet to be tested.

\section{REFERENCES}

Geospec Constants Ltd., 1999. Rb-Sr Isotopic Analysis for Winspear Resources Ltd. De Beers Canada Mining Inc. internal report, June 1999.

Gurney, J.J. and Kirkley, M.B., 1996. Kimberlite Dyke Mining in South Africa, Africa Geoscience Review, Vol.3, pp 191-201.

Hammer, P.T.C., Clowes, R.M. and Ramachandran, K., 2003(in prep.). High-resolution Seismic Reflection Imaging of a Thin, Diamondiferous, Kimberlite Dyke. To be submitted to Geophysics.

Kirkley, M.B., 2001. The Snap Lake kimberlite dyke of the Slave Province: Comparisons and Contrasts with Kaapvaal kimberlite dykes, Slave-Kaapvaal Workshop, Merrickville, Ontario, 5-9 Sept 2001, Extended Abstracts, pp. 183-185.

McCallum, M.E., 2000. Preliminary Evaluation of the Snap Lake Kimberlite Dyke System Geometry, De Beers Canada Mining Inc. internal report, prepared for Winspear Resources, August 2000.

Stubley, M.P., 1998. Bedrock Geology of the Snap Lake Area. De Beers Canada Mining Inc. internal report, prepared for Winspear Resources with accompanying 1:10,000 Scale Map, December 1998.

Stubley, M.P., 2000. Geology of the Northern Snap Lake Area. De Beers Canada Mining Inc. internal report, prepared for Winspear Resources with accompanying 1:10,000 Scale Map, February 2000.

Contact: DA McBean, 400-111 Dunsmuir St. Vancouver, BC, Canada, V6B 5W3, E-mail:

duncan.mcbean@ca.debeersgroup.com 